\title{
OPPORTUNITIES FOR THE IMPROVEMENT OF PUBLIC AND PRIVATE PARTNERSHIP
}

\author{
Lina Marcinkevičiūtė ${ }^{1}$, Jolanta Vilkevičiūtè \\ ${ }^{1}$ Assoc. Prof. Vytautas Magnus University, Universiteto sr. 10, Lithuania, \\ E-mail.lina.marcinkeviciute@vdu.lt \\ ${ }^{2}$ Lector, Vytautas Magnus University, Universiteto sr. 10, Lithuania, \\ E-mail.jolanta.vilkeviciute@vdu.lt
}

Public and private partnership has been seen as an important factor in delivering high quality public services by upgrading or creating public infrastructure. By disposing of resources of different sectors in a sustainable manner, utilizing their advantages, it is possible to satisfy the needs of the society qualitatively and efficiently, which the state is constitutionally obliged to ensure and satisfy when performing its functions. Sectors are different; therefore, the analysis of these differences requires finding the points of interaction. The article sought to elucidate the theoretical aspects of PPPs using scientific databases and opinions of various authors. Structured questionnaires (public and private) assess the advantages and disadvantages of PPP forms. Potential operational opportunities related to EU and Lithuanian PPP strategic and programming documents were proposed.

Key words: Public and private partnership, strategic and programming documents.

JEL Codes: R58, Z18.

Received 0108 2019, Accepted 20092019

\section{Introduction}

Global practice shows that public and private partnership (hereinafter referred to as the PPP) can become an effective way to create and maintain state assets, provide public services and make them more accessible as well as provide other benefits. However, it is necessary to assess whether the implementation of partnership projects is an effective and useful solution for the state and consumers. This assessment is very complex, encompassing legal, financial, managerial, and engineering aspects of the partnership project, and that poses a lot of challenges.

Therefore, the analysis of partnership forms, types, their strengths and weaknesses, as well as the development of tools would facilitate making and implementation of decisions in the PPP.

Copyright (C) 2019 The Authors. Published by Vytautas Magnus University. This is an openaccess article distributed under the terms of the Creative Commons AttributionNonCommercial 4.0 (CC BY-NC 4.0) license, which permits unrestricted use, distribution, and reproduction in any medium, provided the original author and source are credited. The material cannot be used for commercial purposes. 
It can be seen that there are different practices for the assessment of PPP benefits. Usually they are fragmented, and do not cover the entire assessment process. It is important to systematise these practices to assess their disadvantages and advantages and to build complex tools to address PPP problems based on these results.

These tools depend on the assumptions employed in them, e.g. how should project implementation risks be assessed, what should be the rate applicable to future cash flows, etc. The justification for these assumptions is the object of scientific research. Tools created based on science-based results facilitate decision-making by PPP investment planners, project developers and assessors when choosing the partnership form.

This, in turn, creates preconditions for more efficient use of public funds when creating and maintaining infrastructure and providing public services. The object of the study is the advantages and disadvantages of PPP. The aim of the study is to present opportunities for PPP improvement after identifying the advantages and disadvantages of PPP.

\section{Theoretical analysis}

There are plenty of scientific articles in the field of PPP; however, it cannot be said that all areas are analysed evenly. There is a great deal of fragmentation, but there are studies that examine PPP forms, factors leading to a successful implementation of a partnership, risks relevant for both sectors, etc.

Most often, the relevance of investment into public infrastructure is based on scientific, economic, financial, and social perspectives. While analysing the aforementioned problems, most researchers (Bednarek et al., 2012; Carbonara, Costantino, Pellegrino, 2014; Moszoro, 2014; Sarmento, Renneboog, 2016), emphasize the importance of PPP assessment, which could identify the most efficient ways of providing the public infrastructure and services, and determine optimal conditions for the provision of public services.

Many scientific papers (Gouveia, Raposo, 2012; Moro Visconti, 2014; Wojewnik-Filipkowska, Trojanowski, 2013) present studies analysing the potential of the private sector to improve the quality and efficiency of the provision of public services. Other authors of scientific studies (Fernandes, Ferreira, Moura, 2015; Tsamboulas, Verma, Moraiti, 2013; Yin Wang, 2015) point to the success factors of PPP, stating their advantages and disadvantages (Table 1).

It can be said that the main advantages of PPP are cost reduction in order to improve quality and stimulate innovation by attracting capital to other projects; the main drawbacks are the quality and price ratio of projects, their longevity (well beyond the tenure of decision-makers), the private sector's fear of risk, and the public's lack of information about projects planned for implementation or ongoing projects. 
Table 1. Advantages and disadvantages of PPP

(Korf, 2012; Bella, 2013; Austin, 2012)

\begin{tabular}{|c|c|}
\hline Advantages of PPP & Disadvanta \\
\hline $\begin{array}{l}\text { Limited financial capacity of the government. } \\
\text { The deficit in funds for upgrading the existing } \\
\text { infrastructure, maintaining of the level of } \\
\text { activity achieved and running the project is } \\
\text { noticeable }\end{array}$ & $\begin{array}{l}\text { When partnership project related to public- } \\
\text { sector payments are deferred to the future, } \\
\text { there are negative public sector fiscal } \\
\text { indicators of later periods (it is difficult to } \\
\text { predict and assess all factors that may } \\
\text { influence the performance of future } \\
\text { activities) }\end{array}$ \\
\hline $\begin{array}{l}\text { Cost reduction and quality improvement. The } \\
\text { partnership is effective in attracting } \\
\text { competitive companies, providing quality } \\
\text { services and ensuring their relatively low cost }\end{array}$ & $\begin{array}{l}\text { Inadequate possibility of risk distribution } \\
\text { when modernizing public governance, when } \\
\text { certain risk elements, such as excessive } \\
\text { segmentation of the public sector, inability } \\
\text { to coordinate the abundance of public and } \\
\text { private institutions (agencies, commissions, } \\
\text { temporary organizational formations), are } \\
\text { forming }\end{array}$ \\
\hline $\begin{array}{l}\text { Risk management. Risk is distributed among } \\
\text { the public and private sectors by assigning a } \\
\text { greater share of the risk to the party that will be } \\
\text { able to manage and control it best }\end{array}$ & $\begin{array}{l}\text { Higher funding costs than borrowing } \\
\text { through public finances. Due to improperly } \\
\text { concluded contract or asymmetry of } \\
\text { information, such long-term partnerships } \\
\text { can get a high price, which will be a burden } \\
\text { for several generations }\end{array}$ \\
\hline $\begin{array}{l}\text { Maximum benefit. Transfer of individual } \\
\text { services to the control of private sector through } \\
\text { privatization or on the grounds of private and } \\
\text { public partnership. The main motive for the } \\
\text { transfer of public sector services to the private } \\
\text { sector is the motive that a private operator } \\
\text { would work more efficiently than the public } \\
\text { sector, because private operator is seeking } \\
\text { profit }\end{array}$ & $\begin{array}{l}\text { Identification of risks of failure to ensure } \\
\text { enforcement control and their allocation to } \\
\text { partners who are able to manage them with } \\
\text { the least resources available (but the public } \\
\text { sector assumes the main risk of } \\
\text { implementation with various guarantees and } \\
\text { discounts to attract private investors) }\end{array}$ \\
\hline $\begin{array}{l}\text { Better Public Governance - the public sector } \\
\text { focuses on the result. Promotion of competition } \\
\text { between service providers, pursuit of efficiency } \\
\text { through contract management, orientation to } \\
\text { the satisfaction of customer needs }\end{array}$ & \multirow{2}{*}{$\begin{array}{l}\text { Private interests can dominate over the } \\
\text { public ones (redundancies, higher taxes for } \\
\text { end users) by commercializing services } \\
\text { provided by the public sector, they may not } \\
\text { have any alternatives, or they may be very } \\
\text { expensive, not accessible to all, thus } \\
\text { preventing the development of individual } \\
\text { choice }\end{array}$} \\
\hline $\begin{array}{l}\text { The capital is attracted for other projects, } \\
\text { innovations are stimulated. Each partner must } \\
\text { be able to invest in the partnership, both } \\
\text { tangible (money, infrastructure, land, etc.) and } \\
\text { intangible resources such as power, } \\
\text { information, knowledge, etc. }\end{array}$ & \\
\hline
\end{tabular}


There is a general belief that the key role in PPP development lies with each country's government, which can either encourage or suppress partnership initiatives based on legal regulation. Based on the data of document analysis it is established that each country can choose the PPP regulatory framework that best meets its national needs. The key documents governing PPP activities in the EU and Lithuania are described in Table 2.

Table 2. Lithuanian and EU documents that regulate PPP activity

\begin{tabular}{|c|c|}
\hline $\begin{array}{l}\text { PPP activity in } \\
\text { ia }\end{array}$ & $\mathrm{U}$ \\
\hline $\begin{array}{l}\text { on Investments of the } \\
\text { ithuania; Law on Public } \\
\text { he Republic of Lithuania; } \\
\text { of the Government of the } \\
\text { uania, approving the program } \\
\text { ion of public and private } \\
\text { 10-2012 of } 7 \text { April 2010; } \\
\text { Minister of Economy of the } \\
\text { ania "On the approval of the } \\
\text { s for the implementation of } \\
\text { the promotion of public and } \\
\text { ip of } 2010-2012 \text { " of } 4 \text { June } \\
0 \text { of the Government of the } \\
\text { huania, approving the Rules } \\
\text { ion and implementation of } \\
\text { irtnership projects. } \\
\text { of the Minister of Economy } \\
\text { ic of Lithuania "On the } \\
\text { iiteria for Determining the } \\
\text { ublic-Private Partnership and } \\
\text { of the Methodological } \\
\text { is for the Expediency of the } \\
\text { ivate Partnership". } \\
\text { is for the use of competitive } \\
\text { d by the order No. 1S-140 of } \\
\text { e Public Procurement Office } \\
\text { 2010. } \\
\text { Accounting Standard } \\
\text { eements" }\end{array}$ & $\begin{array}{l}\text { Communication from the Commission to the } \\
\text { European Parliament, the Council, the } \\
\text { European Economic and Social Committee } \\
\text { and the Committee of the Regions - } \\
\text { Mobilising private and public investment for } \\
\text { recovery and long-term structural change: } \\
\text { developing Public Private Partnerships of } 24 \\
\text { November 2009; } \\
\text { European Commission Green paper on } \\
\text { public-private partnerships and Community } \\
\text { Law on public contracts and concessions; } \\
\text { Opinion on the Green paper on public-private } \\
\text { partnerships and Community Law on public } \\
\text { contracts and concessions; } \\
\text { Communication from the Commission to the } \\
\text { European Parliament, the Council, the } \\
\text { European Economic and Social Committee } \\
\text { and the Committee of the Regions on Public- } \\
\text { Private Partnerships and Community Law on } \\
\text { Public Procurement and Concessions } \\
\text { European Commission Interpretative } \\
\text { Communication on the Application of } \\
\text { Community Law on Public Procurement and } \\
\text { Concessions to Officially approved Public- } \\
\text { Private Partnership (OAPPP). } \\
\text { European Commission interpretative } \\
\text { communication on concessions under } \\
\text { European Community law (2000/C 121/02). }\end{array}$ \\
\hline
\end{tabular}

According to the European Court of Auditors (2018), in France and Ireland, the PPP system is functioning only at the central level. In Ireland, implementation of contractual arrangements does not require the amount of both verification procedures and benchmarking that is necessary for the implementation of infrastructure accessibility-based PPP projects. In Greece, the 
PPP system is used only in projects with a cost of less than EUR 500 million, and therefore the requirement for mandatory assessment under PPP legislation is not applicable. Spain does not have a body or department specifically responsible for PPP that could assist in the implementation of PPP projects, and it can therefore be argued that insufficient legal regulation can open the way to various abuses. As (Boyer \& Newcomer (2015), Gordon, Mulley, Stevens, \& Daniels (2013), Gupta et al. (2013), Yin Wang (2015), Wibowo \& Alfen (2015), notes, the success of PPP depends on the capabilities of the public sector and the ability to identify and match the requirements of all stakeholders and to assess the likely benefits of PPP. According to data from the European Court of Auditors, data on essential PPP projects in various EU countries for the period 2000-2014 is described in Table 3 below.

Table 3. 2000-2014 y. PPP projects supported by the EU (in millions of euros, by country)

\begin{tabular}{|l|c|c|c|c|}
\hline \multicolumn{1}{|c|}{ Countries } & $\begin{array}{c}\text { Number of } \\
\text { projects }\end{array}$ & Total cost & $\begin{array}{c}\text { EU } \\
\text { contribution }\end{array}$ & $\begin{array}{c}\text { \% of EU } \\
\text { contribution }\end{array}$ \\
\hline Greece & $\mathbf{8}$ & $\mathbf{6 ~ 8 0 6}$ & $\mathbf{3 3 0 1}$ & $\mathbf{5 8 , 5 3 \%}$ \\
\hline Portugal & 3 & 2379 & 564 & $10,00 \%$ \\
\hline France & $\mathbf{2 1}$ & $\mathbf{9 8 5 6}$ & $\mathbf{3 2 4}$ & $\mathbf{5 , 7 4} \%$ \\
\hline Spain & $\mathbf{4}$ & $\mathbf{2 4 2 2}$ & $\mathbf{3 1 1}$ & $\mathbf{5 , 5 1 \%}$ \\
\hline Poland & 4 & 388 & 272 & $4,82 \%$ \\
\hline Germany & 14 & 2147 & 254 & $4,50 \%$ \\
\hline Italy & 6 & 553 & 210 & $3,72 \%$ \\
\hline United Kingdom & 3 & 2212 & 110 & $1,95 \%$ \\
\hline Belgium & 2 & 686 & 101 & $1,79 \%$ \\
\hline Ireland & $\mathbf{3}$ & $\mathbf{1 2 8 6}$ & $\mathbf{8 1}$ & $\mathbf{1 , 4 4} \%$ \\
\hline Lithuania & 3 & 99 & 40 & $0,71 \%$ \\
\hline Slovenia & 10 & 52 & 36 & $0,64 \%$ \\
\hline Croatia & 1 & 331 & 20 & $0,35 \%$ \\
\hline Malta & 1 & 21 & 12 & $0,21 \%$ \\
\hline Estonia & 1 & 4 & 4 & $0,07 \%$ \\
\hline Altogether & 84 & 29242 & 5640 & 100,00 \\
\hline
\end{tabular}

The largest funding of PPP projects during the analysed period was in Greece, France, and Spain. According to the European Court of Auditors (2018), the costs incurred accounted for about $70 \%$ of the total cost of EU-funded PPP projects for the period 2000-2014 (EUR 20.40 billion out of EUR 29.2 billion), and EU contributions were $71 \%$ of all EU contributions to PPP projects (EUR 4.0 billion out of EUR 5.6 billion). Expenditure in the transport and ICT sectors accounted for $93 \%$ of total EU-funded costs of PPP projects (EUR 27.3 billion out of EUR 29.2 billion). The total costs of the projects was EUR 9.6 billion, and the total amount of EU contributions was EUR 2.2 billion. Projects are financed 
by the Structural Funds and funds of the Cohesion Fund, as well as by financial instruments.

As the (Sambrani, 2014; Silvestre, 2012) notes, public sector decisions on the most efficient ways of public infrastructure and provision of services have an impact on the public's ability to have more and better-quality public services with the same or lower costs. This in turn influences changes of public welfare. PPPs can offer a long-term sustainable approach to social infrastructure development, maximize the benefits provided by assets managed by the public sector and the efficiency of resource use.

\section{Research methods}

The study was conducted in three phases. During the first phase, it was sought to clarify the theoretical aspects of PPP (forms of partnership, their essential advantages and disadvantages, examples of good practice, etc.) through the use of scientific and document content analyses, by using scholarly literature of Lithuanian and foreign authors, publications of scientific databases, articles, as well as program and strategic documents.

During the second phase, a structured questionnaire was used to interview personnel of public and private sector (who were already involved or planned to participate in PPP) (a modified Staple scale was used for evaluation). Respondents had to assess the importance of PPP forms by defining the advantages and disadvantages of PPP forms. The public sector was represented by the following officials: elders and eldership employees, heads of communities, and heads of multifunctional centres. The questionnaire was sent to 60 municipalities of Lithuania and to 546 elderships by e-mail. The private sector was represented by the employees of 25 private companies (who prepared and participated in or just prepared PPP projects).

During the third phase, after identification of the main advantages and disadvantages of PPP, potential opportunities for activities related to EU and Lithuanian PPP strategic and program documents were proposed.

\section{Analysis of results}

When analysing the public sector as the initiator of PPP, it should be emphasized that the partnership is mostly employed in order to share the costs and risks of a particular activity, but the need for partnership is still underestimated when passing other decisions: political, economic or social. This leads to an already common situation where the decisions taken by the government or municipal authorities are repeatedly amended, supplemented, and adjusted.

It can be noted that PPP projects are being implemented when building roads, building bridges, and other publicly significant buildings that require large investments. Private sector resources are used to build and repair hospitals, 
schools, airports, bus and train stations, government buildings, and other. Any activity can be performed independently or through partners. In order to assess the additional contribution that can be achieved through the support of employees of other organizations (other institutions, systems or States), obtained by organizing a specific mutually beneficial version of cooperation. Examples of good practice are presented in the Table 4.

Table 4. Examples of PPP good practice in different countries

\begin{tabular}{|l|l|l|l|}
\hline \multicolumn{1}{|c|}{ Countries } & \multicolumn{1}{|c|}{ Example of PPP } & \multicolumn{1}{|c|}{ Value } & Duration, years \\
\hline $\begin{array}{l}\text { United } \\
\text { Kingdom }\end{array}$ & $\begin{array}{l}\text { Construction of a tunnel across the } \\
\text { English Channel }\end{array}$ & 5 billion pounds & 90 \\
\hline USA & Massachusetts Route 3 Route Project & $\begin{array}{l}\text { \$358 million } \\
\text { dollars }\end{array}$ & 7 \\
\hline Australia & $\begin{array}{l}\text { The merger of Royal North Shore } \\
\text { Hospital and the Community Health } \\
\text { Care Center }\end{array}$ & $\begin{array}{l}\text { dollars } \\
\text { deillion }\end{array}$ & 31 \\
\hline Spain & $\begin{array}{l}\text { Construction of Vigo Hospital, City of } \\
\text { Galicia }\end{array}$ & $\begin{array}{l}\text { \$ 320 million } \\
\text { euros }\end{array}$ & 30 \\
\hline Italy & $\begin{array}{l}\text { Under construction 62 km. section of } \\
\text { motorway Brescia-Bergamo-Milan } 2.3 \text { billion } \\
\text { euros }\end{array}$ & 19,5 \\
\hline
\end{tabular}

According to the data of the Department of Statistics of Lithuania, the total number of PPP concession agreements concluded before 1 January 2018 was 54. The largest number of concessions was concluded in the fields of: waste use, recycling, and treatment (12 agreements); culture, sports, leisure facilities, installations and other infrastructure (13 agreements); energy, including heat, electricity, oil and natural gas extraction, transfer, distribution, and supply (9 agreements), and healthcare (6 agreements).

Most PPP agreements are implemented by Klaipèda City Municipality (6 agreements), Kėdainiai Region Municipality (4 agreements), and Panevėžys City Municipality (4 agreements). One of the best known PPP projects in Lithuania is the Vilnius City Street Lighting Network Renovation and Operation Project, which aimed to introduce advanced technologies in the Vilnius city lighting system and to ensure that street lighting services meet traffic safety, environmental, and other requirements (the term is set for 23 years; project's maximum value). Vilnius City Municipality is implementing a PPP project in the education sector, this project successfully facilitates the construction of Balsiai School, its maintenance and administration (the term is set for 25 years, the end of which is expected in 2035; project value). There is also a large public interest in the implementation of Palanga bypass construction and maintenance project, which aims to divert the transit traffic from the city of Palanga, coming from directions of Klaipeda and Šiauliai and going driving towards Liepaja and back (the term is set for 25 years; project value). The Government of the Republic of Lithuania also passed a decree "On the Implementation of the 
Public-Private Partnership Project "Road Vilnius-Utena"", the purpose of which is to reconstruct the sections of the road Vilnius-Utena of unsatisfactory quality and to constantly maintain them, by ensuring road capacity and traffic safety (the term is set for 13 years; project value 175252 euros).

However, despite successfully implemented PPP projects, it can be seen that the implementation of a number of planned PPP did not actually commence. Often one of the reasons is that feasibility studies do not always show that the implementation of the project through PPP is economically feasible.

During the selection of experts in the empirical study, the data analysed was relied upon, and questionnaires were sent to elderships, municipalities, and private companies that had already participated in PPP by drafting and performing PPP agreements. In addition to the targeted experts, potential PPP participants from both sectors that are planning to participate in the said partnership in the nearest future, participated as well. Table 5 describes respondent assessment of the choice of PPP forms.

Table 5. Opinion of public and private sector respondents on the choice of PPP form, average score (maximum score - 5)

\begin{tabular}{|l|c|c|}
\hline \multicolumn{1}{|c|}{ PPP forms } & $\begin{array}{c}\text { Opinion of public } \\
\text { sector respondents, } \\
\text { score averages }\end{array}$ & $\begin{array}{c}\text { Opinion of private } \\
\text { sector respondents, } \\
\text { score averages }\end{array}$ \\
\hline Service Transactions & 3 & 3,5 \\
\hline Management transactions & 2,8 & 2,8 \\
\hline For rent & 3 & 2,9 \\
\hline Public contracts & 2,4 & 2,6 \\
\hline Concessions & 4 & 4 \\
\hline $\begin{array}{l}\text { Build-Purchase-Operate type transactions } \\
\text { and their variants }\end{array}$ & 1,4 & 1,7 \\
\hline $\begin{array}{l}\text { Build-to-Operate-Transfer type transactions } \\
\text { and their variants }\end{array}$ & 1,2 & 1,2 \\
\hline
\end{tabular}

Experts emphasized the concession (rated 4 points) between the public and private sectors, which could lead to higher added value, improved service quality and efficiency of services. Other forms of PPP were less popular. After identifying the advantages and disadvantages of PPP (in the theoretical context) during the first phase of the study, the experts were asked to identify (in a practical context) the essential disadvantages and advantages (by relevance) and to present suggestions for improvement of PPP activities.

Table 6 presents summarized information on the capabilities of PPP, taking into account the views of both scientists and respondents on the advantages and disadvantages of PPP. 
Table 6. Advantages, disadvantages and opportunities of PPP

\begin{tabular}{|c|c|c|}
\hline Advantages of PPP & Disadvantages of PPP & Opportunities of PPP \\
\hline \multicolumn{2}{|c|}{ Opinions of the respondents } & Opinion of scientists and experts \\
\hline $\begin{array}{l}\text { 1. The necessary } \\
\text { investments in the } \\
\text { public sector and } \\
\text { more efficient } \\
\text { management of public } \\
\text { funds are ensured }\end{array}$ & $\begin{array}{l}\text { 1. Deferring partnership } \\
\text { project related public-sector } \\
\text { payments to the future may } \\
\text { have a negative impact on } \\
\text { future fiscal indicators of } \\
\text { the public sector }\end{array}$ & $\begin{array}{l}\text { 1. After receiving additional funding, public } \\
\text { sector institutions would have the possibility } \\
\text { to implement large-scale infrastructure } \\
\text { projects through a single tender procedure }\end{array}$ \\
\hline $\begin{array}{l}\text { 2. Timely and higher } \\
\text { quality public service } \\
\text { provision that is being } \\
\text { ensured positively } \\
\text { affects the social life } \\
\text { of people }\end{array}$ & $\begin{array}{l}\text { 2. Procurement of services } \\
\text { through PPP takes longer } \\
\text { and costs more when } \\
\text { compared to traditional } \\
\text { public procurement }\end{array}$ & $\begin{array}{l}\text { 2. By combining design, financing, } \\
\text { construction, operation and maintenance } \\
\text { phases under a single agreement, the } \\
\text { application of the entire life approach could } \\
\text { be ensured when long-term benefits are } \\
\text { sought }\end{array}$ \\
\hline $\begin{array}{l}\text { 3. Projects are } \\
\text { implemented on time } \\
\text { and do not require } \\
\text { additional spending of } \\
\text { public sector }\end{array}$ & $\begin{array}{l}\text { 3. Agreements of projects } \\
\text { are long-term, complex and } \\
\text { rigid, because it is difficult } \\
\text { to strategically anticipate } \\
\text { and evaluate all future } \\
\text { factors }\end{array}$ & $\begin{array}{l}\text { 3. Risk sharing and risk allocation to the } \\
\text { party, best capable of managing it, would } \\
\text { allow for an effective allocation of costs in } \\
\text { terms of time }\end{array}$ \\
\hline $\begin{array}{l}\text { 4. Private sector } \\
\text { entities are given the } \\
\text { opportunity to ensure } \\
\text { long-term profits }\end{array}$ & $\begin{array}{l}\text { 4. The scale of the PPP use } \\
\text { has to be matched with the } \\
\text { financial capabilities of the } \\
\text { state, municipality and } \\
\text { eldership }\end{array}$ & $\begin{array}{l}\text { 4. Real and specific service and } \\
\text { maintenance standards would provide a } \\
\text { possibility for a more comprehensive } \\
\text { assessment of the needs and trends related } \\
\text { to the necessary infrastructure }\end{array}$ \\
\hline $\begin{array}{l}\text { 5. The experience } \\
\text { and skills of private } \\
\text { sector are employed }\end{array}$ & & $\begin{array}{l}\text { 5. The planning of a long-term budget, } \\
\text { especially related to the project supervision, } \\
\text { would provide an opportunity to ensure an } \\
\text { adequate level of service throughout the term } \\
\text { of agreement }\end{array}$ \\
\hline $\begin{array}{l}\text { 6. Proper risk-sharing } \\
\text { between partners } \\
\text { reduces risk } \\
\text { management costs }\end{array}$ & & $\begin{array}{l}\text { 6. The creation of a legal and institutional } \\
\text { framework could facilitate the } \\
\text { implementation of projects }\end{array}$ \\
\hline
\end{tabular}

In summary, it should be noted that large-scale PPP projects are mostly funded over a longer period of time, thus there is less incentive to take into account real needs when determining the optimal size of the project. The risk that public sector entities may undertake larger infrastructure projects than actually needed, increases. The developed future demand and use scenarios for the planned infrastructure are optimistic, and the economic benefits and efficiency of the projects are lower than expected.

It can be argued that many of the shortcomings of PPP could be avoided or at least minimized by proper drafting of a PPP agreement. Not only lawyers should be involved in the drafting of such an agreement, but also the experts of the relevant field in which the PPP project is being implemented. 
Other causes of incapacity include the highly complicated process of PPP awarding and the lengthy phase of project coordination, which create a risk of the inflation of the project cost and pose the risk for the proper implementation of the project result; the latter reasons should be addressed in order to avoid artificial obstacles for the project implementation. PPP is characterized by the difficulty of finding a private investor willing to participate in the project, as most of the risk is attributed to a private investor as being able able to manage the risk in the best way possible at the lowest cost. A maximum term of 25 years for the implementation of certain projects, established in the Law on investments, is way too short given the complexity and scope of the projects and therefore prevents the use of PPP in some fields.

It should be emphasized that the need for PPP project implementation in Lithuania is growing, but the centralized management, coordination, and supervision of the PPP process is still not being created, this could help avoid problems related to the implementation of PPP and facilitate their solution. The Central Project Management Agency (CPMA) prepares methodological material, submits proposals for legislation, participates in the practical activity of the implementation of public investment projects through PPP, but the material that it prepares is not binding on the central government institutions or municipalities.

\section{Conclusions}

The highly complicated process of PPP awarding and the lengthy phase of project coordination, which create a risk of the inflation of the project cost and pose the risk for the proper implementation of the project result; the latter reasons should be addressed in order to avoid artificial obstacles for the project implementation.

Real and specific service and maintenance standards would provide a possibility for a more comprehensive assessment of the needs and trends related to the necessary infrastructure.

The planning of a long-term budget, especially related to the project supervision, would provide an opportunity to ensure an adequate level of service throughout the term of agreement.

\section{References}

Austin, E., Seitanidi, M. (2012). Collaborative value creation: A Review of Partnering Between Nonprofits and Businesses: Part I. Value Creation Spectrum and Collaboration Stages [interaktyvus], https://www.researchgate.net/publication/235827130_Partnering.pdf [2018 05 12].

Bednarek, Z., Moszoro, M., Chen, B. L., Liou, F. M., Huang, C. P., \& Moszoro, M. (2012). Optimal Financing Mix of Financially Non-Viable Private-Participation Investment Project with Initial Subsidy // Inžinerine Ekonomika-Engineering Economics, 23(5), 452-461. https://doi.org/10.5755/j01.ee.23.5.3130 [2018 05 12]. 
Bella, J. D., Grant, A., Kindornay, S., Tissot, S. (2013). The Private Sector and Development: Key Concepts [interaktyvus], http://www.nsi-ins.ca/wpcontent/uploads/2013/09/The-Private-Sector-and-Development-Key-Concepts-FINAL-PolicyBrief.pdf [2018 03 15]

Boyer, E. J., \& Newcomer, K. E. (2015). Developing Government Expertise in Strategic Contracting for Public-Private Partnerships. Journal of Strategic Contracting and Negotiation, 1(2), 129-148. https://doi.org/10.1177/2055563615592739 [2018 03 15]

Carbonara, N., Costantino, N., \& Pellegrino, R. (2014). Concession period for PPPs: A win-win model for a fair risk sharing. International Journal of Project Management, 32(7), 1223-1232. https://doi.org/10.1016/j.ijproman.2014.01.007 [2018 03 15]

Europos audito rūmai. 2018. Specialioji ataskaita. Viešojo ir privačiojo sektorių partneryste $\quad \mathrm{ES}$ : daug trūkumų ir ribota nauda. http://publications.europa.eu/webpub/eca/special-reports/ppp-9-2018/lt/ [2018 03 15]

Fernandes, C., Ferreira, M., \& Moura, F. (2015). PPPs - True Financial Costs and Hidden Returns. Transport Reviews, 36(2), 207-227. https://doi.org/10.1080/01441647.2015.1076905 [2018 03 15]

INTOSAI. (2004). Guidelines on Best Practice for the Audit of Risk in Public/ Private

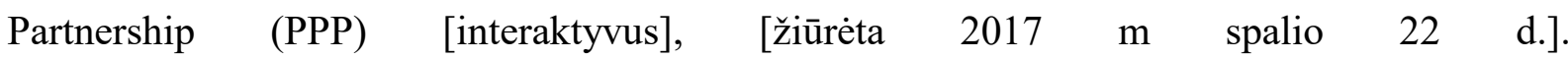
http://icisa.cag.gov.in/resource_files/b36165c6997f5510f033c1cf92199ab9.pdf [2018 03 15]

Gordon, C., Mulley, C., Stevens, N., \& Daniels, R. (2013). How optimal was the Sydney Metro contract? Comparison with international best practice. Research in Transportation Economics, 39, 239-246. https://doi.org/10.1016/j.retrec.2012.06.020 [2018 03 15]

Gouveia, M., \& Raposo, P. (2012). The Public Sector Comparator of PPP: An empirical evaluation in the Healthcare Sector. Incomplete, $\mathrm{x}(\mathrm{x}), 1-21$.

Gupta, A., Gupta, M. C., \& Agrawal, R. (2013). Identification and ranking of critical success factors for BOT projects in India. Management Research Review, 36(11), 1040-1060. https://doi.org/10.1108/MRR-03-2012-0051 [2018 03 15]

Korf, M. (2012). Public - private Partnership: Benefits and Burders of Cooperation [interkatyvus], http://health21 initiative.org/wp-content/uploads/2017/08/2012-Student-paperPPP-Benefits-and-Burdens.pdf [2018 03 15]

LR Finansų ministerija. 2017. Viešojo ir privataus sektorių partnerystès sutarčių pasiskirstymas pagal sritis [interaktyvus], Prieiga per internetą: $<$ https://finmin.lrv.lt/uploads/finmin/documents/files/Sutarciu\%20pasiskirstymas\%20pagal\%2 0sritis\%202017(1).pdf;[2018 03 15]

LR Finansų ministerija. 2010. Partnerystès principo igyvendinimo ịsisavinant ES struktūrinę paramą vertinimas [interaktyvus], [žiūrèta 2017 m lapkričio 06 d.]. Prieiga per internetą:

<http://www.esparama.lt/documents/10157/133671/Partnerystes+igyvendinimo+vertinimo+at askaita.pdf >;

LR finansų ministerija. 2016. Partnerystès principo taikymo, igyvendinant 2014-2020 metų Europos Sajungos fondų investicijų veiksmų programą, gairès [interaktyvus], [žuūrèta $2018 \mathrm{~m}$ kovo 15 d.]. Prieiga per internetą: < 
http://www.esinvesticijos.lt/lt/dokumentai/partnerystes-principo-taikymo-igyvendinant-20142020-metu-europos-sajungos-fondu-investiciju-veiksmu-programa-gaires >;

LIETUVOS RESPUBLIKA. 2014. 2014 - 2020 metų Europos Sajungos fondų investicijų veiksmų programa [interaktyvus], [žiūrèta 2018 m gegužès 15 d.]. Prieiga per internetą:

$<\mathrm{http}: / /$ www.esinvesticijos.1t/uploads/documents/docs/160_61751e80960605f6c8c1a2545e5c 1449.pdf >;

Matonienè, R. (2015). Sustainable regeneration in urban areas [interaktyvus], Prieiga per internetą: < http://urbact.eu/sites/default/files/04_sustreg-web.pdf [2018 03 15]

Moszoro, M. (2014). Efficient public-private capital structures // Annals of Public and Cooperative Economics, 85(1), 103-126. https://doi.org/10.1111/apce.12028 [2018 03 15]

Moro Visconti, R. (2014). Improving Value for Money in Italian Project Finance // Managerial Finance, 40(11), 1058-1077. https://doi.org/10.1108/MF-07-2013-0171 [2018 03 15]

Sambrani, V. N. (2014). PPP from Asia and African Perspective towards Infrastructure Development: A Case Study of Greenfield Bangalore International. Procedia - Social and Behavioral Sciences, 157, 285-295. https://doi.org/10.1016/j.sbspro.2014.11.031 [2018 03 15]

Sarmento, J. M., \& Renneboog, L. (2016). Anatomy of public-private partnerships: their creation, financing and renegotions. International Journal of Managing Projects in Business, 9(2), 94-122. https://doi.org/10.1108/17538370810883819 [2018 03 15]

Silvestre, H. C. (2012). Public-private partnership and corporate public sector organizations: Alternative ways to increase social performance in the Portuguese water sector? Utilities Policy, 22, 41-49. https://doi.org/10.1016/j.jup.2012.01.002 [2018 03 15]

Tsamboulas, D., Verma, a., \& Moraiti, P. (2013). Transport infrastructure provision and operations: Why should governments choose private-public partnership? // Research in Transportation Economics, 38, 122-127. https://doi.org/10.1016/j.retrec.2012.05.004 [2018 03 15]

Wang, Y., \& Liu, J. (2015). Evaluation of the excess revenue sharing ratio in PPP projects using principal-agent models // International Journal of Project Management, 33(6), 1317-1324. https://doi.org/10.1016/j.ijproman.2015.03.002 [2018 03 15]

Wojewnik-Filipkowska, A., \& Trojanowski, D. (2013). Principles of public-private partnership financing - Polish experience // Journal of Property Investment \& Finance, 31(4), 329-344. https://doi.org/10.1108/JPIF-10-2012-0049 [2018 03 15]

Wibowo, A., \& Alfen, H. W. (2015). Government-led critical success factors in PPP infrastructure development. Built Environment Project and Asset Management, 5(1), 121-134. 


\title{
VIEŠOJO IR PRIVATAUS SEKTORIŲ PARTNERYSTĖS TOBULINIMO GALIMYBE்S
}

\author{
Lina Marcinkevičiūtė, Jolanta Vilkevičiūtė \\ Vytauto Didžiojo universitetas
}

Gauta 201908 01, Accepted 20190920

Pasaulinė praktika rodo, kad viešojo ir privataus sektorių partneryste (toliau-VPSP) gali tapti efektyviu būdu kurti ir prižiūrèti valstybès turtą bei teikti viešąsias paslaugas, kartu padaryti jas labiau prieinamas bei teikti kitas naudas. Tačiau būtina ịvertinti, ar partnerystès projektu ịgyvendinimas yra efektyvus ir naudingas sprendimas valstybei ir vartotojams. Šis vertinimas yra labai kompleksinis, apimantis teisinius, finansinius, vadybinius bei inžinerinius partnerystės projekto igyvendinimo aspektus, ir tai kelia daug iššūkių. Todẻl partnerystès formų, rūšių, jų privalumų ir trūkumų analizė bei įrankių kūrimas, leistų palengvinti sprendimų prièmimą ir ịgyvendinimą VPSP. Galima pastebėti, kad egzistuoja ịvairių praktikų VPSP naudai vertinti. Dažniausiai jos būna fragmentinès, neapimančios viso vertinimo proceso. Aktualu šias praktikas sisteminti ịvertinti jų privalumus bei trūkumus ir remiantis šiais rezultatais kurti kompleksinius įrankius VPSP problemoms spręsti. Straipsnyje buvo siekiama išsiaiškinti VPSP teorinius aspektus, naudojant mokslines duomenų bazes ir ịvairių autoriu nuomones. Struktūrizuotu anketavimu (viešajame ir privačiuose sektoriuose) įvertinti VPSP formų privalumai ir trūkumai. Pasiūlytos potencialios veiklos galimybès, susijusios su ES ir Lietuvos VPSP strateginiais ir programiniais dokumentais.

Raktiniai žodžiai: viešoji ir private partnerystè, strateginiai ir programiniai dokumentai.

JEL kodai: R58, Z18. 